\title{
Cervical Spine Ganglioneuroma: A Case Report
}

\author{
Misagh Pourdonya ${ }^{1}$, Zhila Kazemi ${ }^{1}$ and Mehdi Chiniforoush ${ }^{2 *}$ \\ ${ }^{1}$ Medical Student, Ardabil University of Medical Sciences, Iran
}

${ }^{2}$ Pathology Assistant Professor, Anatomical Sciences Department, Ardabil University of Medical Sciences, Iran

Submission: December 13, 2017; Published: December 19, 2017

*Corresponding author: Mehdi Chiniforoush, Pathology Assistant Professor, Anatomical Sciences Department, Ardabil University of Medical Sciences, Iran, Tel: +989144510017; Email: reseteam.2020@gmail.com

\begin{abstract}
Spinal and paraspinal tumors comprise a wide variety of histological types. About $1 \%$ of this neoplasm's are Ganglioneuroma and a small proportion of them may invaginate through the intervertebral foramina causing cord compression. The recent case is about a 23 year old male referring to Fatemi Hospital of Ardabil University of medical sciences with the right extremities hemiparesis and after primary clinical examinations, taking MRI and CT scan; cervico-occipital tumor was diagnosed. Then, the patient was hospitalized at males' neurosurgery ward. He was operated at the same hospital; the tumor was evacuated completely and for exact survey and further studies were sent to pathology. In macroscopic view, smooth tissue containing paramorphic irregular gray components diagnosed Ganglioneuroma at histopathology study/ microscopic view was observed.
\end{abstract}

Keywords: Ganglioneuroma; Cervical Spine; Ardabil

\section{Introduction}

Ganglioneuromas are rare, slow growing; benign tumors that generally arise from the ganglion cells of the sympathetic chain, but they may also arise from sympathetic nerves as well as from peripheral nerves. They represent the most benign form of neurogenic tumor with $60 \%$ of them occurring in children and young adults [1-5]. The ratio of male to females is approximately 3:2. They occasionally grow to large size but total excision using microsurgical techniques is often possible, and may be curative. Ganglioneuroma are considered, as a rule, benign tumors. However, in exceptional cases, intra-tumoral areas of malignant transformation, metastasis, and the development of malignant peripheral tumors arising from ganglioneuromas have been described [6-10]. Although they usually occur in relation to the adrenal medulla and sympathetic chain in the retroperitoneal and retropleural spaces, they may be also being found along in the intestinal tract, and occasionally in a peripheral nerve. Multiple locations are possible. They have also been described in association with Neurofibromatosis diseases $[11,12]$.
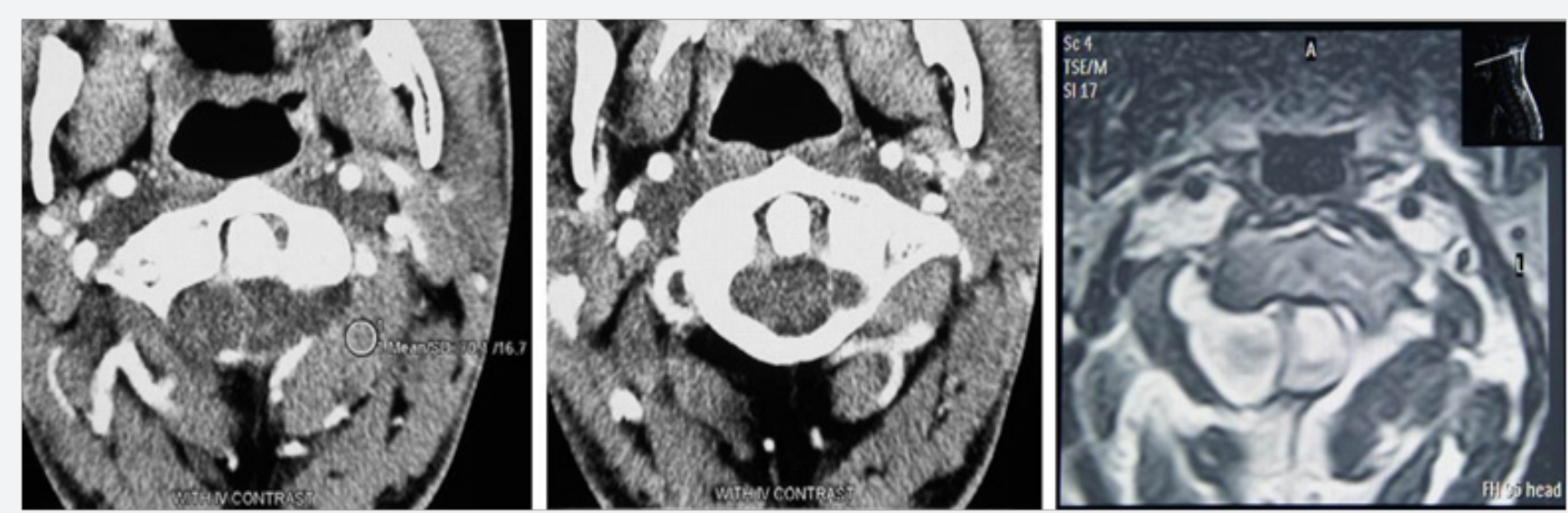

Figure 1: CT scan and MRI finding that show an extra axial tumor at the C1 \& C2 levels. Also, it confirmed Ganglioneuroma disease. 
A 23 year old man who hospitalized at males' neurosurgery ward with right extremities hemiparesis which had been started for one year. After clinical and neurological examinations, the first diagnosis, Cervico-occipital tumor was proposed. Then for the final diagnosis MRI \& CT scan were recommended (Figure 1). Having diagnosed a vast extra axial tumor at the C1 \& C2 levels at MRI, Neurinoma was considered. His laboratory tests revealed the patient had leukocytosis (20.2 per microliter) with an erythrocyte count of 4.08 per microliter and hematocrit of $36.3 \%$. Other factors were about normal. Later that day the patient underwent a laminectomy operation on his C1 \& C2 levels and the tumor of that region which concurrently was intra and extradural completely was evacuated. After operation, he had a suitable general condition, sensory and motor function tests of extremities and his right side hemi paresis were considerable improved. Observing smooth tissue containing paramorphic irregular gray components in macroscopic view, Ganglioneuroma at histopathology study and microscopic view was diagnosed (Figure 2).

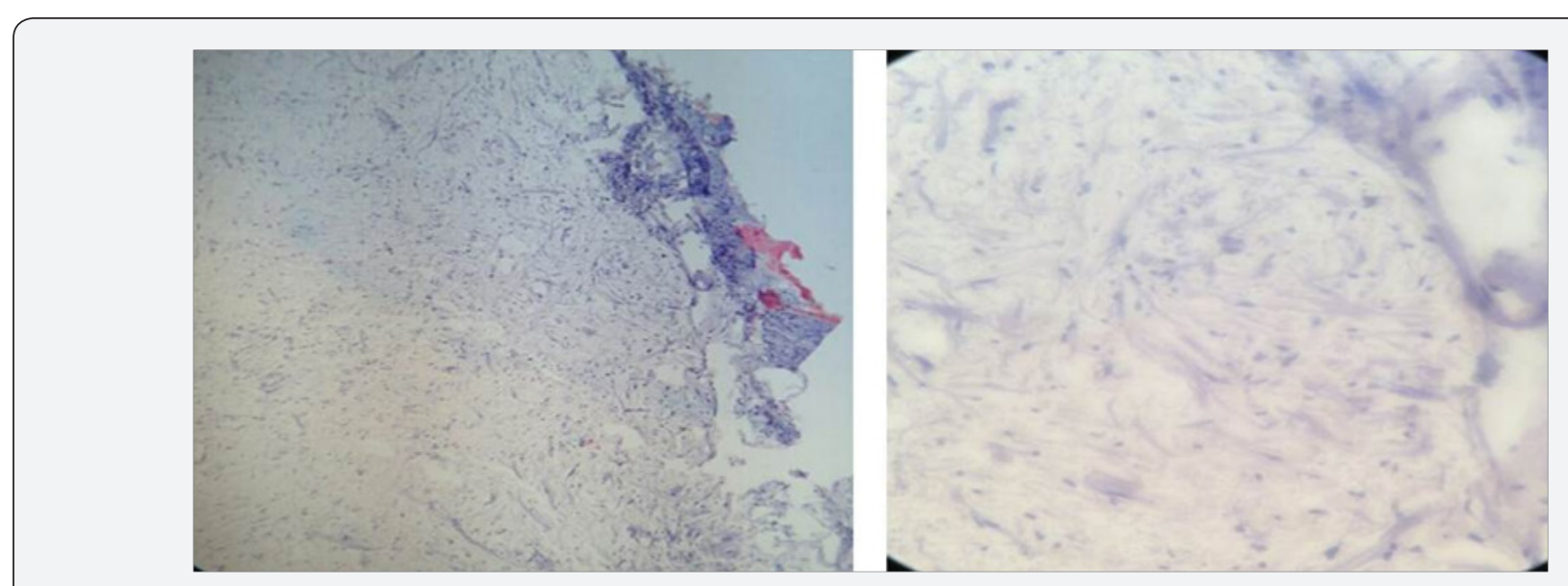

Figure 2: Histopatological result of Ganglioneuroma diseases that confirmed CT scan and MRI finding.

\section{Discussion}

Ganglioneuroma reside within a class of neuronal tumor in which the neoplastic cells express a mature neuronal phenotype. This type of tumor consists of well-differentiated large pyramidalshaped ganglion cells embedded within a scanty stromal of spindle cells [13]. Ganglioneuroma are usually white, firm and encapsulated, slow-growing tumors. Microscopic examination reveals large ganglion cells and areas of smaller lymphocyte-like cells within a matrix of fibrous and Schwann cells. Multinucleate cells with a well-defined nucleolus in each nucleus are commonly found [4]. As diagnosis of ganglioneuroma is based on the absence of necrosis or immature ganglion cells [2], the entire tumor must be examined to rule out areas of malignant transformation. Although ganglioneuroma can produce symptoms related to the large volume they may attain, most of them are asymptomatic and can be diagnosed incidentally by palpation in cases of superficial location $[2,14]$, or on radiographic studies [11]. In some series, 0.8 to $3.5 \%$ of ganglioneuromas were dumbbell tumors $[1,4]$. It is also well known that ganglioneuroma at or near the cervical spine is extremely uncommon $[15,16]$. Regarding treatment, complete excision is the best option [2]. When there is spinal cord compression surgical decompression must be undertaken as soon as possible $[4,15]$. If a complete resection can be achieved, there is no evidence supporting the use of any adjuvant postoperative therapy in the management of ganglioneuroma $[2-5,16]$.

\section{Conclusion}

Ganglioneuroma occurring within the spinal column are exceedingly rare and may grow to a large size. Despite this size and the common involvement of both intra and extra-spinal compartments, favorable outcome, with good functional recovery is often possible after complete excision using microsurgical techniques..

\section{References}

1. Shepard RH, Sutton D (1958) Dumbbell Ganglioneoromata of the spine with a report of four cases. Br J Surg 45(192): 305-317.

2. Barthelemy I, Belveze P, Emering C, Reynaud P, Beaujard H, et al. (1998) Cervical Ganglioneuroma. Review, apropos of a case. Rev Stomal Chir Maxillofac 99(4): 210-213.

3. Fagan CJ, Swischuk LE (1974) Dumbbell Neuroblastoma or Ganglioneuroma of the Spinal Canal. AJR 120(2): 453-460.

4. Miura Y, Okumichi T, Yoshioka K, Okumichi K, Kajihara H (1993) Successful excision of a "dumb-bell" shaped ganglioneuroma of the posterior mediastinum with a large intraspinal component. Eur J Surg 159(11-12): 635-638.

5. Mutluer S, Ersahin Y, Binatli O, Demirtas E (1993) Dumbbell ganglioneuroma in childhood. Chil Nerv Syst 9(3): 182-184.

6. Chandrasoma P, Shibata D, Radin R, Brown LP, Koss M (1986) Malignant peripheral nerve sheath tumor arising in an adrenal ganglioneuroma in an adult male homosexual. Cancer 57(10): 2022-2025.

7. Drago G, Pasquier D, Pinel N, Rouault Plantaz V, Dyon JF, et al. (1997) Malignant Peripheral Nerve Sheath Tumor Arising in a "de novo" 
ganglioneuroma: a case report and review of the literature. Med Pediatr Oncol 28(3): 216-222.

8. Garvin H, Lack EE, Berenberg W, Frantz CN (1984) Ganglioneuroma presenting with differentiated skeletal metastases. Cancer 54(2): 357360.

9. Kulkarni AV, Bilbao JM, Cusimano MD, Muller PJ (1998) Malignant transformation of ganglioneuroma into spinal neuroblastoma in an adult. Case report. J neuro surg 88(2): 324-327.

10. Ricci A, Parham DM, Woodruff M, Callihan T, Green A, et al. (1984) Malignant nerve sheath tumors arising from ganglioneuromas. Am J Surg Pathol 8(1): 19-29.

11. Geraci AP, de Csepel J, Shlasko E, Wallace SA (1998) Ganglioneoroblastoma and ganglioneuroma in association with neurofibromatosis type 1: report of three cases. J Child Neurol 13(7): 356-358.
12. Suetake K, Niwa J, Okuyama T, Shimoyama N, Ishidate T (1993) Ganglioneuroma in the cervical ganglion with neurofibromatosis-2: a case report. No Shinkei Geka 21(7): 629-632.

13. Stout A (1974) Ganglioneuroma of the sympathetic nervous system. Surg Gynecol Obstet 84(1): 101-109.

14. Regas JS, Sanchez de Toledo J, Marques Gubern A, Tresserra L, Balcells R (1989) Primary cervical tumors of the sympathetic nervous system. Report of 8 cases. Cir Pediatr 2(2): 86-89.

15. Maggi G, Dorato P, Trischitta V, Varone A, Civetta F (1995) Cervical dumbbell ganglioneuroma in an eighteen month old child. A case report. J Neurosurg Sci 39(4): 257-260.

16. Shotton JC, Milton CM, Allen JP (1992) Multiple ganglioneuroma of the neck. J Laryngol Otol 106(3): 277-278.

\section{Your next submission with Juniper Publishers will reach you the below assets}

- Quality Editorial service

- Swift Peer Review

- Reprints availability

- E-prints Service

- Manuscript Podcast for convenient understanding

- Global attainment for your research

- Manuscript accessibility in different formats

( Pdf, E-pub, Full Text, Audio)

- Unceasing customer service

Track the below URL for one-step submission

https://juniperpublishers.com/online-submission.php 